\title{
Peripheral Analgesic and Anti-diarrheal Activities of Leaf of Syzygium cumini (L.) Skeel
}

\author{
Md. Shahidulla Kayser ${ }^{1}$, Rubel Nath ${ }^{1}$, Halima Khatun ${ }^{1}$ and Mohammad A. Rashid ${ }^{2}$ \\ ${ }^{1}$ Pharmacology Research Laboratory, Department of Pharmacy, State University of Bangladesh \\ Dhaka-1205, Bangladesh \\ ${ }^{2}$ Phytochemical Research Laboratory, Department of Pharmaceutical Chemistry, Faculty of Pharmacy \\ University of Dhaka, Dhaka-1000, Bangladesh
}

(Received: July 15, 2018; Accepted: August 1, 2018; Published: January 17. 2019)

\begin{abstract}
Syzygium cumini has been used in folk medicine to treat many diseases. To establish the potential medicinal value of leaves of S. cumini, the current study was carried out to assess the peripheral analgesic and anti-diarrheal activities in mice model. The crude methanol extract and its petroleum ether and chloroform soluble fraction were administered to the experimental mice at a dose of 200- and 400$\mathrm{mg} / \mathrm{kg}$ b.w. (denoted as CME1, CME2, PESF1, PESF2, CLSF1 and CLSF2 respectively) using acetic acid induced writhing method and castrol oil induced anti-diarrheal assay protocol. The extract and its Kupchan fractions exhibited significant $(\mathrm{p}<0.001)$ reduction of writhing response in a dose dependent manner. In the acetic acid-induced writhing test, the activity decreased in the order diclofenac $(75.33 \%)$ $>\operatorname{PESF} 2(70.33 \%)>\operatorname{CME} 2(67.00 \%)>\operatorname{PESF} 1(64.00 \%)>\operatorname{CLSF} 2(61.33 \%)>\operatorname{CME} 1(56.67 \%)$ $>$ CLSF1 $(48.67 \%)$. All the fractions significantly $(\mathrm{p}<0.001)$ attenuated anti-diarrheal effect in a dose dependent manner with the highest activity observed by CME2 $(47.73 \%)$ as compared to standard lopeiramide $(54.55 \%)$. The results of our study, being reported for the first time, provide reasonable indication that the methanol extract of $S$. cumini leaf and its different fractions possess peripheral analgesic and antidiarrheal activities.
\end{abstract}

Key words: Syzygium cumini, Eugenia cumini, Eugenia jambolana, leaf, peripheral analgesic, antidiarrheal activity.

\section{Introduction}

In Bangladesh, folk medicinal practitioners (Kavirajes) are considered as the primary health-care providers to the substantial population in rural as well as the urban areas and are relianton medicinal plants for treatment (Hasan et al., 2010). In folk medicine, the Myrtaceae family is well known for medicinal uses and this family consists of nearly 5950 species in 132 genera (Brito et al., 2007; Christenhusz and Byng, 2016).

Syzygium cumini (L.) Skeel (Synonyms: Eugenia cumini L., Eugenia jambolana Lam.) as one of the potential member of this family is used for several decades in folk medicines to treat many diseases.
S. cumini locally known as Jam, Kalojam and Kalajam, whereas in tribal region it is commonly known as Chaku, Sabri (Mogh), Mojibaong, Musbrisi and Sochi Tobri (Marma).

Traditionally it has been found that the crude forms of seed, fruit, bark and leaf are used to treat various forms of diarrhea (Rahmatullah et al., 2010). Along with traditional uses, many pharmacological profiles including antihyperglycemic, anti-HIV, antioxidant, antibacterial and anticancer activities have also been reported for S. cumini (Villasenor and Lamadrid, 2006; Kusumoto et al., 1995; Singh and Gupta, 2007; Bhuiyan et al., 1996; Afify et al., 2011). Although the seeds, fruits and bark of this

Correspondence to: Mohammad A. Rashid; Tel.: +88-02-9661900-73, Extn. 8137; Fax: +88-02-9667222;

E-mail: r.pchem@yahoo.com 
plant have been investigated for pharmacological activities, the medicinal values of the leaves have not been thoroughly explained. That's why the current study was conducted to investigate the peripheral analgesic and anti-diabetic activities of the leaves of S. cumini.

\section{Materials and Methods}

Plant materials collection, extraction and partitioning: The fresh leaves of $S$. cumini were collected in December, 2017 from Chittagong. They were washed with distilled water to remove debris and were sun dried for several days followed by oven dying for 24 hours at $40^{\circ} \mathrm{C}$. Then the dried leaves were grounded a coarse powder with the help of an electric grinding machine. Approximately $250 \mathrm{gm}$ of the coarse powder was soaked in methanol (1.5 liter) and kept at room temperature for 14 days with occasional shaking and stirring. Fresh cotton plugs followed by Whatman filter paper number 1 were used to filter the extract. The filtered extract was concentrated with a rotary evaporator. Petroleum ether (PESF) and chloroform (CLSF) soluble fractions were generated from crude methanolic extract (CME) by modified Kupchan partitioning method (Van Wagenen et al., 1993).

Experimental animals: For peripheral analgesic and anti-diarrheal investigations Swiss albino mice (20-25 gm, total 48 of either sex) were collected from Animal house of Jahangirnagar University, Savar, Dhaka. The mice were kept in polyvinyl cages and fed with ICDDR,B formulated standard rodent food. To reduce the pain and stress of the experimental mice standard protocols were followed.

Chemicals: Diclofenac and lopeiramide and acetic acid solution (1\%) were collected from Square Pharmaceutical Limited. All other reagents and solvents used to conduct the investigations were of analytical grade and obtained from Phytochemical Research Lab of State University of Bangladesh (SUB).

Peripheral analgesic activity: Total 48 mice of both sexes were randomly divided into 8 groups of 6 mice each. By employing the acetic acid-induced writhing method (Koster et al., 1959; Ahmed et al., 2001; Papia et al., 2016; Razan et al., 2016; Faruk et al., 2015), the peripheral analgesic activity of the samples was assessed in mice. The negative control group received $1 \%$ Tween-80 solution in normal saline. Diclofenac, at a dose of $50 \mathrm{mg} / \mathrm{kg}$ body weight, was administered to the positive control group. At 200 and $400 \mathrm{mg} / \mathrm{kg}$ body weight the crude methanolic extract (CME), and its petroleum ether (PESF) and chloroform (CLSF) soluble fractions were given to the mice of experimental groups. After 40 minutes, $1 \%$ acetic acid at a dose of $10 \mathrm{ml} / \mathrm{kg}$ body weight was administered intra-peritoneally to each animal. An interval of 10 minutes was given for absorption of acetic acid and the number of writhing responses was counted for the following $15 \mathrm{~min}$ period. The equation shown below was used to calculate the percent of writhing inhibition:

\section{Inhibition $(\%)=[(\mathrm{Wc}-\mathrm{Wt}) \times 100] / \mathrm{Wc}$}

Where, Wt and Wc are respectively denoted as the mean number of writhing reflex in the test group and the negative control group.

Antidiarrheal activity: To evaluate the antidiarrheal activity of methanolic crude extract and different fractions of S. cumini, castor oil-induced diarrheal in mice method was followed as described by Shoba and Thomas (2001). In total 48 mice were divided into 8 groups (6 mice in each group) and 1 hour prior to administration of castor oil separate treatment was provided for each group. Tween 80 (1\%) in saline of $10 \mathrm{ml} / \mathrm{kg}$ of b.w. was given to negative control group, lopeiramide was used as positive control group at a dose $50 \mathrm{mg} / \mathrm{kg} \mathrm{b}$.w. and other six groups received the crude extract, petroleum ether soluble fraction and ethyl acetate soluble fraction at a dose of 200 and $400 \mathrm{mg} / \mathrm{kg}$ b.w. Each animal was kept in separate pre-cleaned cage and by oral feeding of castor oil ( $1 \mathrm{ml} / \mathrm{mice})$ diarrhea was induced in the mice. The mice were observed for next 4 hours. To estimate the percentage inhibition of defecation in mice, the following equation was used:

$\%$ Inhibition of defecation $=\left[\left(\mathrm{A}_{1}-\mathrm{A}_{2}\right) / \mathrm{A}_{1}\right] \times 100$

$\mathrm{A}_{1}=$ Mean number of defecation by castor oil

$\mathrm{A}_{2}=$ Mean number of defecation by drug or extract 
Statistical analysis: The values are shown as mean \pm SD and to determine the level of significance between the control group and trial groups ANOVA was used, where the $\mathrm{p}$ values less than 0.05 were considered to be statistically significant.

\section{Results and Discussion}

The crude methanolic extract (CME) of $S$. cumini as well as its petroleum ether (PESF) and chloroform (CLSF) soluble fractions were investigated for assay of peripheral analgesic and anti-diarrheal activity.

The crude extract and its different fractions significantly attenuated the number of writhing movements induced by intraperitoneal administration of acetic acid solution and demonstrated significant level of inhibition (Table 1) in a dose dependent manner.

Table 1. Peripheral analgesic activity (in terms of \% inhibition of writhing) of methanolic extract and different partitions of $S$. cumini.

\begin{tabular}{lcccc}
\hline $\begin{array}{l}\text { Animal } \\
\text { Group }\end{array}$ & Dose & $\begin{array}{c}\text { Number of writhing } \\
\text { (Mean } \pm \text { SEM) }\end{array}$ & t-test value & $\begin{array}{c}\text { \% of Inhibition of } \\
\text { writhing }\end{array}$ \\
\hline Control & $10 \mathrm{ml} / \mathrm{kg}$ & $25.00 \pm 2.00$ & - \\
Diclofenac & $50 \mathrm{mg} / \mathrm{kg}$ & $6.17 \pm 0.48^{* * *}$ & 9.1595 & 75.33 \\
CME 1 & $200 \mathrm{mg} / \mathrm{kg}$ & $10.83 \pm 1.19^{* * *}$ & 6.0807 & 56.67 \\
CME 2 & $400 \mathrm{mg} / \mathrm{kg}$ & $8.25 \pm 0.929 * * *$ & 7.596 & 67.00 \\
PESF 1 & $200 \mathrm{mg} / \mathrm{kg}$ & $9.00 \pm 0.58^{* * *}$ & 7.6862 & 64.00 \\
PESF 2 & $400 \mathrm{mg} / \mathrm{kg}$ & $7.42 \pm 0.61^{* * *}$ & 7.4078 & 70.33 \\
CLSF 1 & $200 \mathrm{mg} / \mathrm{kg}$ & $12.83 \pm 1.19^{* * *}$ & 5.2223 & 48.67 \\
CLSF 2 & $400 \mathrm{mg} / \mathrm{kg}$ & $9.67 \pm 0.88^{* * *}$ & 7.0149 & 61.33 \\
\hline
\end{tabular}

All values are expressed as mean \pm SEM; $\mathrm{n}=6$, *p $<0.05, * * \mathrm{p}<0.01, * * * \mathrm{p}<0.001$ indicates significant compared to control.

Table 2. Anti-diarrheal activity (in terms of \% reduction of diarrhea) of methanolic extract and different partionates of $S$. cumini.

\begin{tabular}{lcccc}
\hline Treatment & Dose (b.w.) & $\begin{array}{c}\text { Number of diarrheal } \\
\text { feces (Mean } \pm \text { SEM) }\end{array}$ & t-test value & $\begin{array}{c}\text { \% Reduction of } \\
\text { diarrhea }\end{array}$ \\
\hline Control & $10 \mathrm{ml} / \mathrm{kg}$ & $7.33 \pm 0.33$ & - & - \\
Lopeiramide & $50 \mathrm{mg} / \mathrm{kg}$ & $3.33 \pm 0.49^{* * *}$ & 6.7082 & 54.55 \\
CME 1 & $200 \mathrm{mg} / \mathrm{kg}$ & $4.83 \pm 0.87^{*}$ & 2.6769 & 34.09 \\
CME 2 & $400 \mathrm{mg} / \mathrm{kg}$ & $3.83 \pm 0.60^{* * *}$ & 5.0932 & 47.73 \\
PESF 1 & $200 \mathrm{mg} / \mathrm{kg}$ & $4.67 \pm 0.67^{* *}$ & 3.5777 & 36.36 \\
PESF 2 & $400 \mathrm{mg} / \mathrm{kg}$ & $4.00 \pm 0.73^{*}$ & 4.1523 & 45.45 \\
CLSF 1 & $200 \mathrm{mg} / \mathrm{kg}$ & $5.67 \pm 0.49$ & 2.7951 & 22.73 \\
CLSF 2 & $400 \mathrm{mg} / \mathrm{kg}$ & $4.17 \pm 0.65^{* *}$ & 4.3137 & 43.18 \\
\hline
\end{tabular}

All values are expressed as mean \pm SEM; $\mathrm{n}=6,{ }^{*} \mathrm{p}<0.05, * * \mathrm{p}<0.01, * * * \mathrm{p}<0.001$ indicates significant compared to control

As prostaglandin is considered as a pain mediator, it can be assumed that the plant extract and fractions might hinder either the biosynthesis of prostaglandin or the binding of prostanoids to their receptors. Otherwise, the extractives may have the ability to inhibit the production of neuronal mediators (Faruk et al., 2015; Duarte et al., 1988; Sikder et al., 2013). It has been reported that the leaves of $S$. 
cumini cointain phenolics, flavonoids, phytosterols, terpenoids, and reducing sugars. Powerful antioxidant such asphenolic and flavonoid types of compounds demonstrate analgesic activity by inhibiting the action of prostaglandins and ultimately give relief from pain sensations (Eshwarappa et al., 2014; Hasan et al., 2010).

Table 2 shows that the methanolic extract and different fractions of $S$. cumini exhibited remarkable anti-diarrheal effect in mice. In comparison to standard lopeiramide $(54.55 \%)$, the range of activity was in between 22.73 to 47.73 and of all the extractives, the petroleum ether soluble fractionate at $400 \mathrm{mg} / \mathrm{kg}$ body weight, demonstrated significant anti-diarrheal effect. Medicinal plants containing flavonoids and terpenoids are known to exhibit antidiarrheal effects (Teke et al., 2010). Hence, flavonoids and terpenoids could be responsible for the anti-diarrheal activity of $S$. cumini.

\section{Conclusion}

The results of our study, being reported for the first time, provide reasonable indication that the methanol extract and its organic soluble partionates of leaves of S. cumini possess peripheral analgesic and anti-diarrheal activities. However, additional studies are necessary to isolate and characterize the active compounds responsible for those activities and producing safer lead molecules for treating many physiological conditions including pain and diarrhea.

\section{References}

Hasan, M.M., Annay, M.E.A., Sintaha, M., Khaleque, H.N., Noor, F.A., Nahar, A., Seraj, S., Jahan, R., Chowdhury, M.H. and Rahmatullah, M. 2010. A survey of medicinal plant usage by folk medicinal practitioners in seven villages of Ishwardi Upazilla, Pabna district, Bangladesh. Am. Eurasian J. Sust. Agri. 4, 326-333.

Afify, A.E.M.M., Fayed, S.A., Shalaby, E.A. and ElShemy, H.A. 2011. Syzygium cumini (pomposia) active principles exhibit potent anticancer and antioxidant activities. Af. J. Pharm. Pharmacol. 5, 948-956.
Ahmed, M., Shikha, H.A., Sadhu, S.K., Rahman, M.T. and Datta, B.K. 2001. Analgesic, diuretic, and antiinflammatory principle from Scopariadulcis. Die Pharm. 56, 657-660.

Bhuiyan, M.S.A., Younus Mia, M. and Rashid, M.A. 1996. Antibacterial principles of the seeds of Eugenia jambolana. Bangladesh J. Bot. 25, 239-241.

Brito, F.A., Lima, L.A., Ramos, M.F.S., Nakamura, M.J., Cavalher-Machado, S.C., Siani, A.C., Henriques, M.G.M.O. and Sampaio, A.L.F. 2007. Pharmacological study of anti-allergic activity of Syzygium cumini (L.) Skeels. Braz. J. Med. Biol. Res. 40, 105-115.

Christenhusz, M.J.M. and Byng, J.W. 2016. The number of known plants species in the world and its annual increase. Phytotaxa 261, 201-217.

Duarte, I.D., Nakamura, M. and Ferreira, S.H. 1988. Participation of the sympathetic system in acetic acidinduced writhing in mice. Braz. J. Med. Bio. Res. 21, 341-343.

Eshwarappa, R.S.B., Iyer, R.S., Subbaramaiah, S.R., Richard, S.A. and Dhananjaya, B.L. 2014. Antioxidant activity of Syzygium cumini leaf gall extracts. Bioimpacts. 4,101-107.

Faruk, M.A., Khan, M.F., Mian, M.Y., Rahman, M.S. and Rashid, M.A. 2015. Analgesic and anti-diarrheal activities of Aganosma dichotoma (Roth) K. Schum. in Swiss-Albino mice model. Bangladesh Pharm. J. 18, 15-19.

Hasan, S.R., Hossain, M.M., Akter, R., Jamila, M., Mazumder, M.E.H., Alam, M.A., Faruque, A., Rana, S. and Rahman, S. 2010. Analgesic activity of the different fractions of the aerial parts of Commelina benghalensis Linn. Int. J. Pharmacol. 6, 63-67.

Koster, R., Anderson, M. and De Beer, E.J. 1959. Acetic acid for analgesic screening. Proc. Soc. Exp. Bio. Med. 18, 412-415.

Kusumoto, I.T., Nakabayashi, T., Kida, H., Miyashiro, H., Hattori, M., Namba, T. and Shimotohno, K. 1995. Screening of various plant extracts used in ayurvedic medicine for inhibitory effects on human immunodeficiency virus type $1 \quad$ (HIV $\square 1)$ protease. Phytother. Res. 9, 180-184.

Papia, S., Rahman, M.M., Rahman, M.M., Adib, M. and Khan, M.F. 2016. In vitro membrane stabilizing and in vivo analgesic activities of Boehmeria glomerulifera Miq. in Swiss-Albino mice model. Bangladesh Pharm. J. 19, 185-189. 
Rahmatullah, M., Khatun, M.A., Morshed, N., Neogi, P.K., Khan, S.U.A., Hossan, M.S., Mahal, M.J. and Jahan, R. 2010. A randomized survey of medicinal plants used by folk medicinal healers of Sylhet Division, Bangladesh. Adv. Nat. Appl. Sci. 4, 52-62.

Razan, M.R., Rahman, M.M., Tahia, F., Hossain, M.K. and Rashid, M.A. 2016. Analgesic and Antidiarrheal Activities of Leaf of Podocarpus nerifolius D. Don. Bangladesh Pharm. J. 19, 215-218.

Sikder, M.A.A., Rashid, R.B., Islam, F., Hossian, A.K.M.N., Siddique, A.B., Kabir, S., Haque, M.R., Rahman, M.S. and Rashid, M.A 2013. Screening of ten medicinal plants of Bangladesh for analgesic activity on Swiss-albino mice. Ori. Pharm. Exp. Med. 13, 327-332.

Singh, N. and Gupta, M. 2007. Effects of ethanolic extract of Syzygium cumini (Linn) seed powder on pancreatic islets of alloxan diabetic rats. Indian J. Exp. Biol. 45, 861-867.
Shoba, F.G. and Thomas, M. 2001. Study of anti-diarrheal activity of four medicinal plants in castor oil induced diarrhea. J. Ethnopharmacol. 76, 73-76.

Teke, G.N., Kuiate, J.R., Kuete, V., Teponno, R.B., Tapondjou, L.A. and Vilarem, G. 2010. Antidiarrheal activity of extracts and compound from Trilepisium madagascariense stem bark. Indian J. Pharmacol. 42, 157-163.

VanWagenen, B.C., Larsen, R., Cardellina, J.H., Randazzo, D., Lidert, Z.C. and Swithenbank, C. 1993. Ulosantoin, a potent insecticide from the sponge Ulosa ruetzleri. J. Org. Chem.58, 335-337.

Villasenor, I.M. and Lamadrid, M.R.A. 2006. Comparative anti-hyperglycemic potentials of medicinal plants. $J$. Ethnopharmacol. 104, 129-131. 